\title{
PENGARUH GAYA KEPEMIMPINAN ISLAM DALAM MENINGKATKAN ETOS KERJA KARYAWAN PADA PT. PERKEBUNAN NUSANTARA IV UNIT KEBUN TIMUR
}

\author{
Sudirman \\ Program Studi Ekonomi Syariah \\ Program Pascasarjana IAIN Batusangkar
}

\begin{abstract}
This research is aimed to examine and find out empirical evidence of the Islamic leadership style on employee work ethic. Sampled used in this research are employees at during afdelling I-VI. The data are collected using purposive sampling method. The analysis of this research employs simple linear regression. Result show that Islamic Leadership Style have significant and positive effect on employee work ethic with the magnitude of the influence of $9 \%$ and the contribution of the variable Islamic Leadership Style worth 27.3\%.
\end{abstract}

Key Word : Gaya Kepemimpinan Islam, Etos Kerja Karyawan

\section{PENDAHULUAN}

Proses kegiatan suatu organisasi atau perusahaan pasti akan mengalami hambatan dan rintangan dalam mencapai tujuannya. Salah satunya adalah upaya dalam peningkatan sumber daya manusia dalam perusahaan atau organisasi. Banyak yang telah mengalami kemunduran bahkan kegagalan dalam mencapai tujuannya hanya karena permasalahan peningkatan sumber daya manusia.

Salah satu sasaran pengolahan sumber daya manusia pada fungsi manajemen organisasi adalah menyangkut masalah kepemimpinan. Seseorang yang ditunjuk sebagai pemimpin maupun yang diakui oleh anggota sebagai orang yang pantas memimpin mereka, dialah yang menjalankan fungsi organisasi tersebut. Menurut Veithzal, Rivai (2004:2) kepemimpinan adalah proses yang mempengaruhi atau memberi contoh kepada pengikutpengikutnya melalui proses komunikasi dalam upaya mencapai tujuan organisasi.

Perilaku seorang pemimpin dapat memberikan pengaruh yang akan menimbulkan pemahaman tersendiri dan berdampak terhadap kondisi psikologis bawahan, sehingga bawahan yang melihat, mengamati dan meniru perilaku pemimpin yang ditampilkan atasan. Sebaliknya apabila perilaku kepemimpinan yang 
ditampilkan atasan sebagai sesuatu yang tidak sesuai dengan harapannya maka akan berpengaruh kurang baik terhadap kinerja Karyawan.

Oleh karena itu untuk meningkatkan kembali etos kerja Karyawan tersebut, maka salah satu faktor yang perlu diperhatikan adalah menyangkut gaya kepemimpinan yang diterapkan oleh pemimpin-pemimpin pada perusahaan yang dapat menunjang karyawannya bekerja, beribadah dan berinovasi unggul.

Salah satu penentu maju mundurnya sebuah perusahaan atau kantor tergantung kepada seorang pimpinan yang mengarahkan Karyawan atau pegawainya serta meningkatkan etos kerja bawahannya. Pengelolaan aktivitas setiap organisasi harus benar-benar tepat agar tujuan organisasi yang telah direncanakan dapat tercapai secara maksimal. Karena setiap aktivitas organisasi tidak lepas dari daya guna manusia tenaga kerja atau pegawainya.

Toto Tasmara (2002:15) Etos berasal dari bahasa Yunani (ethos) yang berarti sikap, kepribadian, watak, karakter, serta keyakinan atas sesuatu. Sikap ini tidak hanya dimiliki oleh individu, tetapi juga oleh kelompok bahkan masyarakat. Etos dibentuk oleh berbagai kebiasaan, pengaruh budaya, seta sistem nilai yang diyakini. Kerja adalah aktivitas yang dilakukan karena ada dorongan untuk mewujudkan sesuatu sehingga tumbuh rasa tanggung jawab yang besar untuk menghasilkan karya atau produk yang berkualitas, atau juga sesuatu yang direncanakan. Disisi lain makna kerja bagi seorang muslim adalah suatu upaya yang sungguhsungguh dengan mengerahkan seluruh aset, fikiran, dan dzikirnya untuk mengaktualisasikan atau menampakkan arti dirinya sebagai hamba Alloh yang harus menundukkan dunia dan menempatkan dirinya sebagai bagian dari yang terbaik (Khoiru Ummah) atau dengan bekerja manusia itu dapat memanusiakan dirinya.

Dalam penerapan etos kerja, Peranan pimpinan sangat penting, karena pemimpin merupakan pihak yang bertanggung jawab dalam organisasinya. Disini yang dimaksud kepemimpinan adalah kegiatan seorang pemimpin atau atasan yang memberikan pembinaan, motivasi, mempengaruhi atau mengontrol pikiran atau tingkah laku anggotanya untuk mencapai tujuan. Anoraga, Pandji (2001 : 183).

Gaya Kepemimpinan Islam adalah kegiatan menuntun, membimbing, memandu dan menunjukkan jalan yang diridhoi Allah SWT. Jadi orientasi utama dalam kepemimpinan Islam adalah keridhaan Allah. Penerapan kepemimpinan Islam diperlukan dalam suatu 
organisasi, agar para pemimpin organisasi dapat menjalankan tugas yang diembannya dengan baik, selalu memberikan motivasi spiritualitas pada bawahannya sehingga tujuan keberhasilan tidak hanya didasarkan pada materi, tetapi juga memperhatikan aspek religius. Tebba Sudirman (2003:68)

Berdasarkan observasi awal yang penulis lakukan dilapangan, maka penulis dapat mengidentifikasi permasalahan tentang etos kerja karyawan PT. Perkebunan Nusantara IV Unit Kebun Timur, yaitu : karyawan dalam aktivitas bekerja belum memiliki kejujuran tepat waktu dan merasa terpaksa dalam bekerja, kurang komitmen dalam bekerja, tidak memanfaatkan waktu bekerja dengan baik, produktifitas tidak maksimal, kurang kerjasama antar pekerja.

Berdasarkan hal-hal diatas gejala yang dapat dilihat antara lain adalah : ditemukan kurangnya pengaruh gaya kepemimpinan islam dalam meningkatkan etos kerja karyawan PT Perkebunan Nusantara IV Unit Kebun Timur. sehingga sebagai upaya dalam mengembalikan keyakinan dan cara pandang karyawan dibutuhkan keteladanan, bimbingan, pembinaan dan pelatihan. Gaya Kepemimpinan Islam itu sangat diperlukan dalam suatu organisasi, agar para pemimpin organisasi dapat menjalankan tugas yang diembannya dengan baik, untuk dapat memberikan motivasi spiritualitas pada bawahannya sehingga tujuan keberhasilan tidak hanya didasarkan pada materi, tetapi juga memperhatikan aspek religialitas/religius dalam artian bekerja adalah ibadah.

Gaya kepemimpinan adalah suatu gaya yang dapat memaksimum kan produktivitas, kepuasan kerja, pertumbuhan, dan mudah menyesuai kan dengan segala situasi.

Agama islam mengajarkan bahwa kepemimpinan yang baik adalah kepemimpinan yang selalu berpegang pada Al qur'an dan hadist. Para pakar menelusuri Al qur'an dan hadist (Rivai : 2004, 113) menetapkan empat dasar sifat yang harus dipenuhi oleh para nabi yang pada hakikatnya adalah pemimpin umatnya, yaitu :

Pertama, Shiddiq ; Yakni seorang pemimpin, senantiasa berprilaku yang benar dan jujur dalam dalam sepanjang kepemimpinannya. Benar dalam mengambil keputusankeputusan dalam perusahaan yang bersifat strategis, menyangkut visi/misi, dalam menyususn obyektif dan sasaran serta efektif dan efisien dalam implementasi dan operasionalnya dilapangan.

Sikap jujur berarti selalu berlandaskan ucapan, keyakinan, serta perbuatan berdasarkan ajaran islam. Tidak ada kontradiksi dan 
pertentangan yang disengaja antara ucapan dan perbuatan. Oleh karena itulah, Allah memerintahkan orangorang yang beriman untuk senantiasa memiliki sifat shiddiq dan juga dianjurkan untuk menciptakan lingkungan yang shiddiq. Sebagaimana firman Allah SWT :

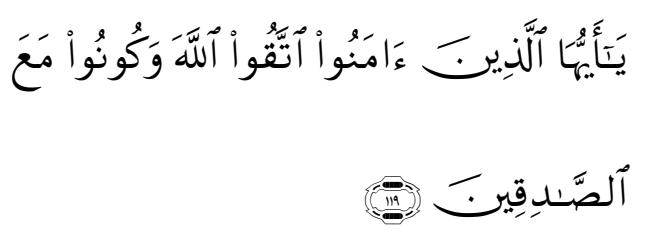

"Hai orang-orang yang beriman bertakwalah kepada Allah, dan hendaklah kamu bersama orang-orang yang benar.” (QS. At-Taubah 9:119)

Selain itu dalam sebuah hadist, Rasullulah SAW bersabda :

"Hendaklah kalian jujur (benar) karena kejujuran mengantarkan kepada kebaikan. Dan kebaikan aan mengantar ke dalam surga. Seseorang selalu berusaha untuk jujur akan dicatat oleh Allah sebagai orang jujur. Dan jauhilah oleh kamu sekalian kidzb (dusta), karena dusta itu akan mengantarkan kepada kejahatan. Dan kejahatan akan mengantarkan ke dalam neraka. Seseorang yang selalu berdusta akan dicatat Allah sebagai pendusta"(HR. Bukhari).

Kedua, Amanah; atau kepercayaan, yang menjadikan dia memelihara sebaik-baiknya apa yang diserahkan kepadanya baik dari
Tuhan maupun dari orang-orang yang dipimpinnya, sehingga tercipta rasa aman bagi semua pihak.

Ketiga, Fathonah ; yaitu kecerdasan yang melahirkan kemampuan menghadapi dan menanggulangi persoalan yang muncul seketika sekalipun. Fathonah dapat diartikan : Intelektual, kecerdikan, atau kebijaksanaan. Pemimpin perusahaan yang fathonah artinya pemimpin yang memahami, mengerti, dan menghayati secara mendalam segala hal yang menjadi tugas dan kewajibannya.

Keempat, Tabliqh ; penyampai-an yang jujur dan bertanggung jawab, atau dapat diistilahkan dengan "keterbukaan". Sifat Tabliqh artinya komunikatif, dan argumentatif. Dalam penyampaian sesuatu, ia menyampaikan dengan benar (berbobot) dan denga tutur kata yang tepat (bil-hikmah). Jika ia seorang Pemimpin (leader) dalam perusahaan, maka haruslah menjadi seorang yang mampu mengkomunikasikan visi dan misinya dengan benar kepada karyawan dan stackholdernya.

\section{Peranan Kepemimpinan dalam Organisasi}

Peran pemimpin zaman sekarang tidak terlepas dari kepemimpinan masa lalu sebagaimana contoh kepemimpinan

Muhammad 
Rasululloh. Achmad Sanusi dan Sobri Sutikno (2009:29-31)

1. Peran penentu arah.

Peran ini merupakan peran Dimana seorang pemimpin berperan sebagai penentu arah, seorang pemimpin menyampaikan visi, mengkomunikasikannya, memotivasi pekerja dan rekan, serta meyakinkan orang bahwa apa yang dilakukan merupakan hal yang benar, dan mendukung partisipasi pada seluruh tingkat dan pada seluruh tahap usaha menuju masa depan.

2. Agen perubahan

Dalam konteks perubahan, lingkungan eksternal adalah pusat. Ekonomi, sosial, teknologi, dan perubahan politis yang terjadi secara terus-menerus. Para pemimpin yang efektif harus secara konstan menyesuaikan terhadap perubahan ini dan berpikir ke depan tentang perubahan potensial dan yang dapat dirubah.

3. Juru bicara

Pemimpin sebagai juru bicara untuk visi, harus mengkomunikasikan suatu pesan yang mengikat semua orang agar melibatkan diri dan menyentuh visi organisasi secara internal dan secara eksternal.

4. Pelatih.

Pemimpin sebagai pelatih, menjaga pekerja untuk memusatkan pada realisasi visi dengan pengarahan, memberi harapan, dan membangun kepercayaan yang penting bagi organisasi dan visinya untuk masadepan. Agar berhasil dalam pencapaian suatu tujuan maka diperlukan seorang pemimpin yang profesional, Dimana ia memahami akan tugas serta dapat melaksanakan peranannya sebagai pemimpin. Disamping itu, pemimpin harus menjalin hubungan kerja sama yang baik dengan bawahan, sehingga terciptanya suasana kerja yang aman, tentram, dan memiliki suatu kebebasan dalam mengembangkan gagasannya dalam rangka tercapainya tujuan bersama yang telah ditetapkan.

Faktor-faktor yang Mempengaruhi Kepemimpinan dalam Organisasi

Ada beberapa faktor yang mempengaruhi kepemimpinan dalam organisasi diantaranya sebagai berikut. Achmad Sanusi dan Sobri Sutikno (2009:86)

\section{Keahlian dan Pengetahuan}

Keahlian dan pengetahuan yang dimaksud adalah latar belakang pendidikan yang dimilikinya, sesuai tidaknya latar belakang pendidikan dengan tugas-tugas kepemimpinan yang menjadi tanggung jawabnya, pengalaman kerja sebagai pemimpin, apakah pengalaman telah dilakukan mendorong dia untuk memperbaiki dan mengembangkan kecakapannya dan keterampilannya dalam memimpin. Jenis Pekerjaan atau 
Lembaga Tempat Pemimpin Itu Melaksanakan Tugas Jabatannya Tiap organisasi yang tidak sejenis memiliki tujuan yang berbeda, dan menuntut cara-cara pencapaian yang tidak sama. Oleh karena itu, tiap jenis organisasi memerlukan perilaku dan sikap kepemimpinan yang berbeda pula.

2. Sifat-Sifat Kepribadian Pe-mimpin

Sifat dan kepribadian memimpin juga sangat mempengaruhi kepemimpinan seseorang. Kita mengetahui bahwa secara psikologis manusia berbeda-beda sifat, watak, dan kepribadiannya. Ada yang selalu besikap keras dan tegas, tetapi ada pula lemah dan kurang berani. Dengan adanya perbedaan-perbedaan watak dan kepribadian yang dimiliki masing-masing pemimpin, meskipun beberapa orang pemimpin memiliki latar pendidikan yang sama dan diserahi tugas pemimpin dalam organisasi yang sejenis, karena perbedaan kepribadiannya akan menimbulkan perilaku dan sikap yang berbeda pula dalam menjalankan kepemimpinannya.

3. Sifat-Sifat Kepribadian Pengikut nya

Tentang sifat-sifat kepribadian pengikutya itu mengapa dan bagaimana anggota kelompok menerima dan mau menjalankan perintah atau tugas- tugas yang diberikan oleh pemimpin .
Berdasarkan faktor-faktor tersebut, maka jelaslah bahwa kesuksesan pemimpin dalam aktivitasnya dipengaruhi oleh faktorfaktor yang dapat menunjang untuk berhasilnya suatu kepemimpinan, oleh sebab itu, suatu tujuan akan tercapai apabila terjadinya keharmonisan dalam hubungan atau interaksi yang baik antara atasan dengan bawahan, motivasi diri untuk berprestasi, kedewasaan dan keleluasaan dalam hubungan sosial.

Kepemimpinan Organisasi dalam Pandangan Islam

Secara substantif, Islam tidak mengajarkan tentang statifikasi manusia, baik dari segi keturunan, ras, warna kulit, posisi kekuasaan, struktur jabatan politik atau kepemilikan harta benda, Islam hanya mengenal manusia dalam derajat ketakwaan. Syarifuddin Jardi (2010:53). Dalam Islam telah digariskan bahwa setiap diri adalah pemimpin (minimal untuk diri sendiri) dan untuk kepemimpinan itu ia dituntut untuk bertanggung jawab. Kepemimpinan Islam dikembangkan di atas prinsip-prinsip etika tauhid. Pernyataan utama seorang pemimpin yang telah digariskan oleh Allah SWT dalam firmannya QS. Al-Anfaal ayat 27.

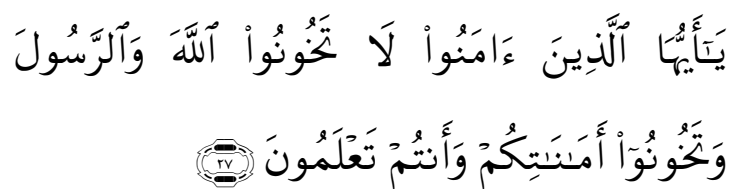


"Hai orang -orang yang beriman, janganlah kamu mengkhianati Allah dan Rasul (Muhammad) dan (juga) janganlah kamu mengkhianati amanat-amanat yang dipercayakan kepadamu, sedang kamu Mengetahui. (Q.S. Al-Anfaal :27)

Di antara kewajiban yang ditunaikan seorang pemimpin dihadapan bawahan adalah sebagai berikut :

1. Menunjukkan suri tauladan yang baik atas semua aktivitas yang dilakukan.

2. Memiliki interaksi sosial yang baik dengan bawahan dan menghormati pendapat mereka .

3. Mengajak bawahan untuk bermusyawarah dan meng-hormati pendapat mereka.

4. Melatih bawahan untuk menjalankan tugas dengan amanah.

5. Memiliki kepercayaan terhadap kemampuan bawahan, dan mendelegasikan beberapa wewenang, dan Melakukan inspeksi, pengawasan dan audit terhadap kinerja bawahan secara amanah. Achmad Sanusi dan Sobri Sutikno (2009: 138).

Etos kerja yang baik akan timbul apabila mental setiap pekerjaan sudah mempunyai dasar yang baik dan benar dalam memandang sesuatu pekerjaan, tidak mungkin akan ada perubahan dan perkembangan secara fisik sebelum ada perubahan sikap mental dan spiritual suatu kaum sebagai mana firman Allah dalam al-Qur'an surat Ar-Ra'd ayat 11, yang memperingatkan kaummnya.

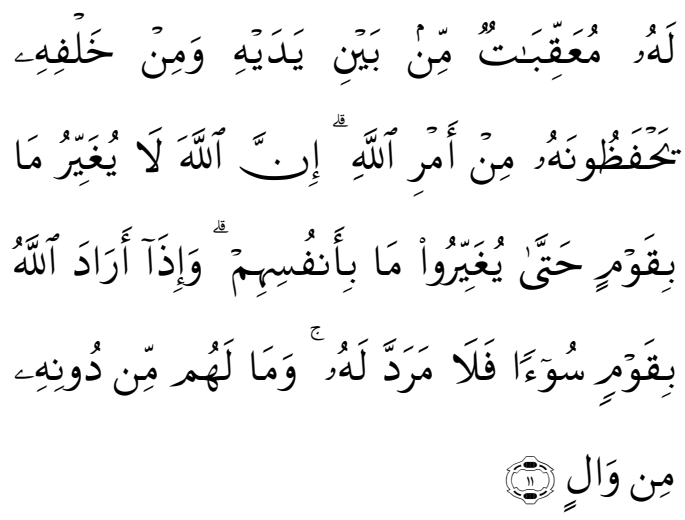

"Bagi manusia ada malaikatmalaikat yang selalu mengikutinya ber-giliran, di muka dan di belakangnya, mereka menjaganya atas perintah Allah. Sesungguhnya Allah tidak merubah keadaan sesuatu kaum sehingga mereka merubah keadaan yang ada pada diri mereka sendiri . dan apabila Allah menghendaki keburukan terhadap sesuatu kaum, Maka tak ada yang dapat menolaknya; dan sekali-kali tak ada pelindung bagi mereka selain Dia.. (Ar-Rad:11)

Sudirman Tebba (2003:37), dalam bukunya Membangun Etos Kerja dalam Perspektif tasawuf, sikap ikhlas membuat orang bertanggung jawab terhadap pekerjaannya dan tempat ia bekerja. Sikap ikhlas itu 
sangat penting dalam pekerjaan dan etos kerja.

\section{a. Memiliki kejujuran.}

Di dalam jiwa seorang yang jujur itu terdapat komponen nilai rohani yang memantulkan berbagai sikap yang berpihak kepada kebenaran dan sikap moral yang terpuji (morallyupright).

b. Memiliki komitmen.

Yang dimaksudkan dengan commitment (dari bahasa Latin: committere, toconnect, entrust-the state ofbeing obligatedor emotional lyimpelled) adalah keyakinan yang mengikat (aqad) sedemikian kukuh nya sehingga membelenggu seluruh hati nuraninya dan Kemudian meng gerakkan perilaku menuju arah tertentu yang diyakininya (ïtiqad).

c. Istiqomah atau kuat pendirian.

Pribadi muslim yang profesional dan berakhlak memiliki sikap konsisten. Konsistensi itu diperlukan untuk mencapai target yang sudah ditentukan, baik kualitas maupun kuantitasnya. Sikap konsisten telah melahirkan kepercayaan diri yang kuatdan memiliki integritas serta mampu mengelola stres dengan tetap penuh gairah.

d. Hidup berhemat dan efisien.

Dia akan selalu berhemat karena seorang mujahid adalah seorang pelari marathon, lintas alam, yang harus berjalan dan lari jarak jauh. Karenanya, akan tampaklah dari cara hidupnya yang sangat efisien di dalam mengelola setiap "resources" yang dimilikinya.

e. Berorientasi pada produktifitas.

Seorang muslim akan berhitung efisien, artinya selalu membuat perbandingan antara jumlah keluaran (performance) dibandingkan dengan energi (waktu tenaga) yang dia keluarkan (produktifitas: keluar-an yang dihasilkan berbanding dengan masukan dalam bentuk waktu dan energi).

f. Memperkaya jaringan silahturahmi.

Bersilaturrahmi berarti membuka peluang dan sekaligus mengikat simpul-simpul Informasi dan menggerakkan kehidupan. Manusia yang tidak mau atau enggan bersilaturrahmi untuk membuka cakrawala per-gaulan sosialnya atau menutup diri dan asyik dengan dirinya sendiri, pada dasarnya dia sedang mengubur masa depannya. Dia telah mati sebelum mati.

\section{Kerangka Berfikir}

Untuk mengetahui masalah yang akan dibahas, perlu adanya kerangka pikir yang merupakan landasan dalam penelitian masalah yang bertujuan untuk menemukan, mengembangkan dan menguji kebenaran suatu penelitian dapat digambarkan adalah sebagai berikut : 


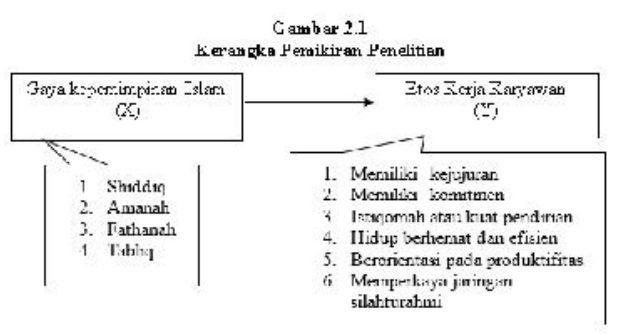

Variabel Independen (X) = Gaya Gaya Kepemimpinan Islam

Gaya Kepemimpinan Islam Adalah Kegiatan menuntun, membimbing, memandu, menunjuk-kan jalan yang diridhoi Allah SWT. Meneladani Sifat-sifat Rasululloh SAW dalam memimpin yaitu Siddiq, Amanah, Fathanah dan Tabliq.

Variabel Dependen $(\mathrm{Y})=$ Etos kerja

Karyawan

Pengertian Etos Kerja Karyawan adalah cara pandang yang diyakini seorang muslim bahwa bekerja itu bukan saja untuk memuliakan dirinya, tetapi sebagai suatu manifestasi dari amal sholeh dan mempunyai nilai ibadah sangat luhur. (K.H. Toto Tasmara)

\section{Hipotesis}

Hipotesis merupakan jawaban sementara yang masih harus dibuktikan kebenaranya melalui penelitian (Sugiyono, 2010:85). Hipotesis dalam penelitian ini adalah: $\mathrm{H}_{\mathrm{o}}$ : Diduga Gaya Kepemimpinan Islam berpengaruh positif dan signifikan dalam meningkat-kan Etos Kerja Karyawan Pada PT.
Perkebunan Nusantara Unit Kebun Timur.

$\mathrm{H}_{\mathrm{i}}$ : Diduga Gaya Kepemimpinan Islam tidak berpengaruh positif dan signifikan dalam meningkatkan Etos Kerja Karyawan Pada PT Per-kebunan Nusantara Unit Kebun Timur

\section{METODE PENELTIIAN}

Tempat penelitian ini adalah PT. Perkebunan Nusantara IV Unit Kebun Timur yang ada di Desa Batu Sondat, Kecamatan Batahan, Kabupaten Mandahiling Natal provinsi Sumatera Utara. Waktu penelitian bulan September s/d November 2018.

Populasi penelitian ini adalah semua karyawan PT Perkebunan Nusantara IV Unit Kebun Timur yang aktif pada tahun 2017/2018. Jumlah populasi sebanyak 300 orang. Populasi tersebut memiliki karakteristik tersebar secara merata dan homogen. Sampel penelitian ini dipilih dengan menggunakan teknik random Sampling. Dari hasil perhitungan yang dilakukan dengan mengambil 20\% dari masing-masing penyebaran populasi yang merata dan homogen di afdeling I s/d VI dan kantor inflasmen. Persentase ini digunakan untuk penetapan jumlah sampel masing-masing strata. Jumlah sampel dalam penelitian ini adalah sebanyak 50 orang yang dipilih 
mewakili masing-masing strata secara keseluruhan. Hal ini dilakukan untuk memberi peluang yang sama bagi semua individu yang akan dijadikan sampel.

\section{PEMBAHASAN}

Data variabel etos kerja karyawan PTPN IV Unit Kebun Timur diperoleh dari 18 butir pernyataan. Idealnya skor variabel etos kerja karyawan PTPN IV Unit Kebun Timur menyebar antara 74 (terendah) dan 132 (tertinggi). Selanjutnya diperoleh skor rata-rata (mean) sebesar 114,50 skor tengah (median) sebesar 126,92 skor yang banyak muncul (mode) 114 dan simpangan baku (standar deviation) 8,89909. Tingkat pencapaian responden pada variabel etos kerja karyawan PTPN IV Unit Kebun Timur adalah hasil bagi rata-rata dengan skor maksimum ideal yaitu $114,50 / 132=0.8674$ atau $86 \%$ (termasuk kategori baik). Hasil ini menunjukkan bahwa etos kerja karyawan PTPN IV Unit Kebun Timur tersebut baik.

Beberapa hal yang penulis pandang mempengaruhi kondisi ini adanya upaya peningkatan kualitas sumber daya manusia yang memperlihatkan frekuensi tinggi, baik yang dilakukan oleh managemen dan maneger. Upaya-upaya yang dilakukan terhadap karyawan tersebut antara lain :
1. Karyawan memiliki kesadaran terhadap upaya kerja maksimal yang merupakan ibadah dengan program pembinaan mental spiritual keagamaan.

2. Karyawan merasa masih kurangnya penghargaan dan perhatian terhadap kebutuhan dan mengatasi permasalahan mereka.

3. Menyatukan kerja sama karyawan dalam satu timework dengan ikatan tali silaturohim.

4. Mewujudkan pemimpin yang menjadi tauladan bagi bawahan.

Etos kerja merupakan hal yang penting yang dimiliki individu didalam bekerja. Setiap individu pekerja memiliki karakteristik yang berbeda-beda, maka dalam meningkatkannya dibutuhkan pembinaan, bimbingan, dan perhatian secara berkesinambungan dengan kepemimpinan yang ada sehingga menghasilkan budaya kerja yang maksimal.

Data variabel Gaya Kepemimpinan Islam diperoleh dari 22 butir pernyataan, idealnya skor variabel gaya kepemimpinan islam menyebar antara 57 (terendah) dan 103 (tertinggi). Selanjutnya diperoleh skor rata-rata (mean) sebesar 91,02 skor tengah (median) sebesar 97,58 skor yang banyak muncul (mode) 99 dan simpangan baku (standard deviation) 9,75515. Tingkat pencapaian responden pada variabel 
gaya kepemimpinan islam adalah hasil bagi rata-rata dengan skor maksimum ideal yaitu $91,02 / 103=0,8836$ atau 88\% (termasuk kategori baik). Hasil ini menunjukkan bahwa pengaruh gaya kepemimpinan islam di PTPN IV Unit Kebun Timur baik.

\section{Analisis}

Data penelitian ini dianalisis dengan menggunakan rumus statistik korelasi dan regresi. Analisis dengan menggunakan teknik statistik ini dapat dilakukan hanya bila data yang akan dianalisis memenuhi beberapa persyaratan yaitu : (1) data masingmasing variabel berdistribusi normal, (2) data setiap kelompok (variabel) bersifat homogen, dan (3) garis regresi yang menghubungkan masing-masing variabel bebas (X) dengan variabel terikat $(\mathrm{Y})$ bersifat linear.

Pemeriksaan persyaratan analisis dilakukan dengan menggunakan bantuan program SPSS Versi 21.0. Dari hasil analisis dapat simpulkan bahwa Gaya Kepemimpinan Islam (X) memiliki pengaruh positif dan signifikan dalam meningkatkan Etos Kerja Karyawan (Y) PTPN IV Unit Kebun Timur serta memenuhi kenormalan dan hommogenitas data, karena itu semua persyaratan untuk penggunaan teknik statistik untuk pengujian hipotesis terpenuhi.

Dari hasil pengolahan data, diketahui untuk instrumen Etos Kerja (Y) diketahui nilai Corrected Item-Total Correlation terkecil o,383, untuk instrumen Gaya Kepemimpinan (X) nilai instrumen terkecil adalah 0,354 .
Nilai-nilai tersebut berada pada ambang batas minimal sebuah item dikatakan sahih.

Dari hasil pengolahan dapat diketahui bahwa nilai keandalan Cronbach's Alpha yaitu untuk instrumen Etos Kerja adalah 0,925 , sedangkan untuk instrumen Gaya Kepemimpinan Islam adalah 0,919. Dari data ini dapat terlihat bahwa nilai Cronbach's Alpha berada pada kisaran diatas 0,60 ini mengindikasikan bahwa semua instrumen penelitian dapat dikatakan reliabel atau dapat dipercaya serta data terdistribusi dengan normal.

\section{Uji Hipotesis}

Hipotesis pertama yang diajukan dalam penelitian ini adalah bahwa "Gaya Kepemimpinan Islam berpengaruh positif dan signifikan dalam meningkatkan Etos Kerja Karyawan PTPN IV Unit Kebun Timur sebesar 0.090 atau $9 \%$ dapat diartikan bahwa besarnya sumbangan atau pengaruh variable Gaya Kepemimpinan Islam di PT Perkebunan Nusantara IV Unit Kebun Timur terhadap etos Kerja karyawan adalah sebesar $9 \%$. Sedangkan sisanya yaitu 91\% dipengaruhi oleh variabel lain diluar model yang tidak diteliti. Hal ini juga berarti bahwa variabel independen mampu memberikan informasi yang dibutuhkan untuk memprediksi variabel dependen.

Hipotesis dalam penelitian ini adalah Gaya Kepemimpinan Islam berpengaruh positif terhadap Etos kerja Karyawan di PT Perkebunan Nusantara IV Unit Kebun Timur. 
Bahwa Gaya Kepemimpinan Islam memiliki nilai Thitung 2.176 dengan koefisien $\beta$ adalah 0.273. Sedangkan nilai Ttabel adalah 1.67655. Berarti nilai Thitung > Ttabel yakni $2.176>$ 1.67655 artinya adalah variabel independen mempengaruhi variabel dependen. Dengan kata lain Gaya Kepemimpinan Islam berbengaruh positif terhadap Etos kerja Karyawan di PT Perkebunan Nusantara IV Unit Kebun Timur.

\section{TEMUAN PENELITIAN}

Berdasarkan hasil penelitian ini diketahui bahwa Gaya Kepemimpinan Islam memiliki pengaruh signifikan terhadap Etos Kerja. Artinya, peran Gaya Kepemimpinan Islam yang diterapkan berhasil memberikan pengaruh dan meningkatkan Etos Kerja karyawan. Ini berarti kegiatan menuntun, membimbing, memandu, menunjukkan jalan yang diridhoi Allah SWT serta meneladani sifat-sifat Rasululloh SAW dalam memimpin yaitu Siddiq, Amanah, Fathanah dan Tabliq mampu memberikan pengaruh positif terhadap cara pandang yang diyakini karyawan bahwa bekerja itu bukan saja untuk memuliakan dirinya, tetapi juga merupakan wujud perbuatan amal sholeh. Sehingga kualitas kerja secara maksimal menjadi prioritas bagi karyawan dan juga dengan ikatan tali silaturahmi antara sesama karyawan akan terwujudnya kerja sama timkerja yang unggul dan terjalin komunikasi yang baik dalam mencapai target/tujuan perusahaan.

\section{PENUTUP}

Dari hasil persamaan regresi linier sederhana diatas diketahui nilai konstanta sebesar 89.622 yang berarti bahwa tanpa adanya pengaruh gaya kepemimpinan islam pada PT Perkebunan Nusantara IV Unit Kebun Timur, etos kerja (Y) nilainya adalah 89.622.

Adapun pengaruh dari variabel Gaya Kepemimpinan Islam di PT Perkebunan Nusantara IV Unit Kebun Timur terhadap Etos Kerja Karyawan ditunjukkan oleh angka 0.273 yang berarti menunjukkan nilai koefisien regresi sejumlah 27,3\%. Hal ini mengindikasikan bahwa jika Gaya Kepemimpinan Islam meningkat satu satuan, maka akan meningkatkan Etos Kerja Karyawan sebesar 27,3\%. Ini berarti Gaya Kepemimpinan Islam yang diterapkan di PT Perkebunan Nusantara IV Unit Kebun Timur akan memberikan pengaruh sebesar 27,3 \% pada Etos Kerja Karyawan.

\section{KEPUSTAKAAN ACUAN}

Anaraga,Panji 2001, Spikologi Kerja, (Jakarta: Rineka Cipta)

Ardana Komang, Dkk, 2009, Perilaku Keorganisasian, (Yogyakarta: GrahaIlmu)

Tasmara Toto, 2002, Membudayakan Etos Kerja Islami, (Jakarta: Gema Insani Press)

Tasmara Toto, 1995, Etos Kerja Pribadi Muslim, (Jakarta: PT. Dana Bhakti Wakaf) 
Aziz Abdul dan Mariyah Ulfah, 2010, Perkapita Selekta Ekonomi Islam Kontemporer, (Bandung : Alfabeta,)

Bangun, Wilson. 2012. Manajemen Sumber Daya Manusia. Erlangga. Jakarta.

Chapra M. Umer, 2000, Islam dan Tantangan Ekonomi, alih bahasa oleh Ikhwan Abidin B, (Jakarta: Gema Insani Press)

Daft, Richard L. 2002. Manajemen Edisi Kelima Jilid Satu. Jakarta: Erlangga.

Dessler, Gary. 2007. Manajemen Personalia, Edisi Ketiga. Jakarta: Erlangga.

Fahrurrozi Aziz dan Erta Mahyudin, 2010, Fiqih Manajemen Aplikasi Nilai-Nilai Ibadah di Dalam Kehidupan, (Jakarta Selatan: Pustaka Al-Mawardi)

Griffin, Ricki W dan Ronal Jebert. 2007. Bisnis Edisi 8. Jakarta: Erlangga.

Guritno, dkk. 2005. Pengaruh Persepsi Karyawan Mengenai Perilaku Kepemimpinan, Kepuasan Kerja dan Motivasi Terhadap Kinerja. JRBI. Vol 1.No 1. Hal:63-74.

Handoko T. Hani 2003, Manajemen, (Yogyakarta: BPFEYogyakarta)

2004. Strategi Organisasi. Cetakan Pertama. Amara Books. Yogyakarta.
2008. Manajemen Personalia dan Sumber Daya Manusia. Yogyakarta : BPFE.

Hutapea, Paruliandan Thoha, Nurianna. 2008. Kompetensi Plus: Teori, Desain, Kasus dan Penerapan untuk HR dan Organisasi yang Dinamis. Jakarta: Gramedia Pustaka Utama.

Ibrahim Abu Sinn Ahmad, 2008, Manajemen Syariah Sebuah Kajian Historis dan Kontemporer,(Jakarta: PT. Rajawali Grafindo Persada)

Jansen Sinamo, 2005, Delapan Etos Kerja Profesional,(Jakarta: Institut Mahardika,)

Jardi Syarifuddin, 2010, Sosiologi Islam dan Masyarakat Modern, (Jakarta: Kencana)

Jusmaliani, 2010, Pengelolaan Sumber Daya Insani, (Jakarta : PT. Bumi Aksara) Kedua. Cetakan Keenam Belas. BPFE.Yogyakarta.

Khasanah Uswatun, 2004, Etos Kerja: Sarana Menuju Puncak Prestasi, (Jogyakarta: Harun )

Malayu, S.P., Hasibuan. 2005. Manajemen Sumber Daya Manusia. Edisi Revisi. Jakarta: Bumi Aksara.

Mangkuprawira, Sjafridan Aida Vitayala Hubeis.2007. Manajemen Mutu Sumber

Moeheriono. 2012. Pengukuran Kinerja Berbasis Kompetensi. 
Edisi Revisi. Cetakan Pertama. Jakarta : Raja Grafindo Persada.

Muhadi Zainuddin dan Abd. Mustaqim, 2005, Studi Kepemimpinan Islam.Telaah Normatif dan Historis, (Semarang: Putra Mediatama press)

Pabundu Tika Moh, 2010, Budaya Organisasi dan Peningkatan Kinerja Perusahaan,(Jakarta: PT. Bumi Aksara)

Rivai, Veithzal dan Mulyadi, Deddy. 2013. Kepemimpinan dan Perilaku Organisasi. Edisi ketiga. Cetakan ke sepuluh. Jakarta: PT. Raja Grafindo Persada.

Sanusi Achmad dan Sobri Sutikno, 2009, Kepemimpinan Sekarang dan Masa Depan dalam Membentuk Budaya Organisas yang Efektif, (Bandung: Prospect)

Sedarmayanti. 2007. Manajemen Sumber Daya Manusia, Reformasi Birokrasi dan Manajemen Pegawai Sipil. Bandung: PT. Refika Aditama.

Siagian, Sondang. 2009. Kita Meningkatkan Produktivitas Kerja. Cetakan Kedua. Rineka Cipta. Jakarta.

Silalahi, Ulber. 2013. AsasAsasManajemen.CetakanKedua. PT.RefikaAditama.

Simamora, Henry. 2004. Manajemen Sumber Daya Manusia, Edisi Ketiga, Cetakan Pertama.
Yogyakarta: Bagian Penerbitan STIE YKPN.

Slamet, Achmad. 2007. Manajemen Sumber Daya Manusia. Universitas Negeri Semarang Press.Semarang.

Solihin Ismail, PengantarManajemen, (Jakarta:Erlangga)

Sutrisno Edy, 2011, Manajemen Sumber Daya Manusia,(Jakarta: Kencana)

Sutrisno, Edy.2010. Manajemen Sumber Daya Manusia. Cetakan kedua. Jakarta: Kencana Prenada Group.

Sutrisno, Edy. 2012. Manajemen Sumber Daya Manusia. Edisi 1. Cetakan Keempat. Prenada Media Group. Jakarta.

Tebba Sudirman, 2003, MembangunEtos Kerja dalam Perspektif tasawuf, (Bandung: Pustaka Nusantara Publishing)

Thoha Miftah, 2009, Kepemimpinan dalam Manajemen, Jakarrta: PT. Raja Grafindo Persada)

Thoha, Miftah. 2010. Perilaku Organisasi: Konsep Dasar dan Aplikasinya. Cetakan kedua puluh. Jakarta: PT. Raja Grafindo Persada.

Veithzal Rivai, 2004, Kiat Memimpin Abad ke-21,(Jakarta: Raja Grafindo) 